\title{
IDENTIFIKASI AKTIVITAS MOLUSKISIDA LARUTAN Smilax Sp TERHADAP HAMA KEONG MAS (Pomacea Canaliculata Lamarck)
}

\author{
Syarifudin Labato, Aung Sumbono, Ratna Prabawati \\ Prodi Biologi Unimuda Sorong
}

Syarifudinlabato96@gemail.com

\begin{abstract}
ABSTRAK
Penelitian ini bertujuan untuk Identifikasi aktivitas moluskisida larutan Smilax $S p$ terhadap hama Pomacea Canaliculata Lamarck. Penelitian dilakukan di Laboratorium MIPA, UNIMUDA SORONG pada bulan Juli 2019 menggunakan daun Smilax Sp untuk mortalitas Pomacea Canaliculata Lamarck. Dirancang dengan tiga perlakuan konsentrasi $(25 \%, 50 \%$, dan 75\%) tiap perlakuan, dan masing-masing sebanyak 10 Pomacea Canaliculata Lamarck. dengan tiga kali ulangan. Data hasil pengamatan mortalitas organisme Diuji prasyarat dan uji hipotesis. Hasil penelitian diperoleh bahwa larutan Smilax $S p$ memiliki aktivitas moluskisida terhadap hama Pomacea Canaliculata Lamarck dengan kosentrasi larutan yang optimal $75 \%$ selama 2 jam.
\end{abstract}

Kata kunci: keong mas, Pomacea canaliculata lamark, Smilax Sp.

\section{ABSTRACT}

This study aims to the identification of the molluscicidal activity of Smilax Sp solution against the Pomacea Canaliculata Lamarck pest. The study was conducted at the MIPA Laboratory, UNIMUDA SORONG in July 2019 using Smilax Sp leaves for the mortality of Pomacea Canaliculata Lamarck. Designed with three concentration treatments $(25 \%, 50 \%$, and $75 \%)$ each treatment, and each of 10 Pomacea Canaliculata Lamarck. with three replications. Data from observations of organism mortality Tested for prerequisites and hypothesis testing. The results of the study obtained that the Smilax Sp solution has a molluscicidal activity against pests Pomacea Canaliculata Lamarck with an optimal solution concentration of $75 \%$ for 2 hours.

Keywords: golden snail, Pomacea canaliculata lamark, Smilax Sp.

\section{PENDAHULUAN}

Hama merupakan salah satu kendala yang dihadapi petani dalam berproduksi. Hama tanaman adalah semua hewan yang karena aktifitas hidupnya merusak tanaman atau hasilnya, sehingga menimbulkan kerugian secara ekonomi. Hewan yang dapat menjadi hama antara lain serangga, tungau, tikus, burung, dan mamalia besar (KBBI). Salah satu jenis hama yakni hewan mollusca (Pomaceae canaliculata Lamarck).

Moluska merupakan hewan lunak yang mempunyai cangkang dan banyak ditemukan di ekosistem mangrove yang hidup di permukaan subsrat maupun di dalam substrat dan menempel pada pohon mangrove (1). Salah satu spesies mulusca yakni Pomaceae canaliculata Lamarck. Keong mas atau keong murbei (Pomacea spp.) dari suku Ampullariidae merupakan keong air tawar pendatang dari Amerika Selatan yang masuk ke Indonesia sekitar awal 1980-an dan menjadi hama tanaman padi yang serius di Indonesia juga di Asia Tenggara (2). Keong mas yang selama ini diidentifikasi sebagai jenis Pomacea canaliculata telah merusak ribuan hektar semai padi, atau tanaman padi berumur muda (2). Maka dilakukanlah penelitianpenelitian pengendalian Pomaceae canaliculata Lamarck.
Upaya pemberantasan keong telah dilakukan oleh program pengendalian schistosomiasis dengan penyemprotan moluskisida Bayluscide setiap 6 bulan sekali. Penggunaan moluskisida kimia memiliki beberapa kelemahan yaitu bahan lebih mahal dan menyebabkan polusi yang lebih besar terhadap lingkungan, yaitu polusi air, tanah dan hewan lain (ikan) (3). Selain dari itu keong mas sangat sulit diberantas.

Faktor utama yang membuat keong mas sulit diberantas adalah kemampuan adaptasinya yang tinggi sehingga dapat hidup di berbagai tipe habitat. Selain itu tingginya daya reproduksi yang ditandai dengan jumlah telur mencapai \pm 8.700 butir per musim reproduksi dan kemampuannya untuk bertahan hidup pada kondisi lingkungan yang kering (estivasi), juga menjadi alasan mengapa keong mas melimpah jumlahnya di alam dan dikategorikan sebagai hama Kemampuan berkembang biak dan adaptasi keong mas yang tinggi tersebut perlu dilakukan suatu penelitian untuk membasmi keong mas secara kimiawi.

Pengendalian Pomaceae canaliculata Lamarck secara kimiawi juga pernah dilakukan, yaitu dengan Brestan dan Dimotrin, namun penggunaannya terbatas karena dapat mencemari sawah dan menyebabkan kematian ikan-ikan di sawah (4), kemampuan 
berkembang biak dan adaptasi Pomaceae canaliculata Lamarck yang tinggi tersebut perlu dilakukan suatu penelitian untuk membasmi Pomaceae canaliculata Lamarck secara kimiawi., maka perlu dilakukan penelitian mengunakan bahan yang tidak berbahahya bagi mahkluk hidup lain selain hewan moluska, yaitu dengan cara memanfaatkan musuh alami yang bisa mengurangi tingkat populasi dari hama Pomaceae canaliculata Lamarck tersebut.

Upaya memberantas hewan moluska mengunakan Beberapa jenis hewan golongan udangudangan, ikan, serangga, burung ,mamalia, serta herpetofauna berpotensi menjadi musuh alami bagi Pomaceae canaliculata Lamarck. Umumya, kelompok hewan tersebut menjadi musuh alami bagi Pomaceae canaliculata Lamarck muda yang bercangkang berukuran kurang dari $12 \mathrm{~mm}$. Meskipun demikian beberapa jenis, kura-kura, burung, kepiting dan tikus dapat memangsa Pomaceae canaliculata Lamarck yang berukuran lebih dari $20 \mathrm{~mm}$ (5). Tetapi di era sekarang musuh-musuh alami keong mas tersebut mulai berkurang, sehingga banyak dari peneliti yang mencoba mengkaji penggunaan jenis-jenis tanaman yang yang dapat dijadikan pengendali hewan moluska.

Beberapa penelitian dilaporkan menggunakan serbuk daun talas (Colocasia Esculenta), serbuk daun nimba (Azadirachta Indica), serbuk daun sukun (Artocarpus Altilis), serbuk eceng gondok (Enghornia Crassipes), serbuk buah pinang (Areca Catechu), serbuk serai (Cymbopogon Citratus), dan serbuk buah mengkudu (Morinda Citrifolia) dapat menekan populasi pertumbuhan Pomaceae canaliculata Lamarck (6).

Pada daerah di bagian pulau Papua belum ada penelitian tentang tanaman asli Papua yang dapat digunakan sebagai anti hama. Tanaman asli Papua seperti Smilax $S p$ merupakan tanaman endemik Kepulauan Papua. Smilax (Smilacaceae) merupakan satu marga tumbuhan yang tersebar pada daerah tropis maupun subtropis, terdiri dari lebih kurang 300 jenis (7). Smilax $S p$ sudah dilakukan pemanfaatannya untuk bidang kesehatan masyarakat terutama untuk obat tradisional. Akar dari beberapa jenis Smilax sp. atau yang dikenal sebagai 'sarsaparilla' telah dimanfaatkan sebagai obat herbal (8) antibakteri, antijamur dan antioksidan (9).

Masyarakat asli Papua menggunakan tanaman Smilax $S p$ sebagai obat pembesar alat kelamin, namun pada jangka waktu pemakaian yang terlalu lama dapat menyebabkan pecahnya pembuluh darah. Berdasarkan efek negatif yang di timbulkan dari penggunaan tanaman Smilax $S p$ maka peneliti membuat penelitian menjadikan larutan Smilax $S p$ sebagai Moluskisida untuk membasmi hewan Pomacea Canaliculata Lamarck. Tujuan penelitian ini adalah untuk mengidentifikasi aktivitas moluskisida larutan Smilax Sp terhadap hama Pomacea Canaliculata Lamarck".

\section{METODE PENELITIAN}

Pendekatan yang dipakai dalam penelitian ini adalah penelitian eksperimen. Penelitian eksperimen merupakan penelitian yang dilakukan dengan manipulasi yang bertujuan untuk mengetahui akibat manipulasi terhadap perilaku individu yang diamati. (10).

Tempat pelaksanaan penelitian ini dilakukan di Laboratorium MIPA, UNIMUDA Sorong di mulai sejak bulan Juli tahun 2019.

Memisahkan daun dari batangnya menggunakan pisau, kemudian di timbang menggunakan timbangan analitik, Cuci daun menggunakan air bersih hingga daun tersebut bersih, setelah itu tiriskan, Haluskan daun menggunakan blender dengan perbandingan air 1:1, Setelah halus, saring daun dengan mengunakan saringan untuk memisahkan cairan dari ampas daun, Siapkan 3 wadah ukuran $6000 \mathrm{ml}$, Masukan air ke dalam masingmasing wadah sebanyak 2000 ml, Kemudian Pomacea canaliculata Lamarck dimasukan kedalam wadah, Teteskan larutan Smilax Sp kedalam wadah yang sudah diberi air dan Pomacea canaliculata lamarck yang mau dibasmi, dan Amati (mortalitas) Pomacea canaliculata Lamarck selama 2 jam.

Populasi dalam penelitian ini yakni tanaman anti hama dan molusca yang diperoleh di Kabupaten Sorong. Sampel yakni tanaman Smilax $S p$ dan Pomaceae canaliculata Lamarck yang di peroleh di Kabupaten Sorong. Tanaman Smilax $S p$ yang dipakai adalah daun segar yang baru di petik, Pomaceae canaliculata Lamarck yang di pakai sebagai sampel adalah 90 ekor dengan berat 60-70 gram.

Bahan yang digunakan yaitu : Daun tumbuhan Smilax Sp yang didapat di Kabupaten Sorong,Air bersih,dan Hewan Pomacea Canaliculata Lamarck.

Alat yang digunakan yaitu : 3 buah wadah ukuran $6000 \mathrm{ml}, 1$ buah gunting, 1 buah blender, 1 buah timbangan (Analitik), 1 buah kamera,

3 buah gelas ukur, 1 buah buku, dan 1 buah pena.

Teknik analisa data terbagi atas 2 bagian, yaitu uji prasyarat dan uji hipotesis. Uji prasyarat menggunakan uji normalitas. Uji hipotesis menggunakan uji mann-whitney. Analisa data dilakukan dengan menggunakan statistik SPSS. Sebelum menguji hipotesis, harus dilakukan uji prasyarat untuk menentukan statistik uji hipotesis yang akan digunakan. Uji prasyarat tersebut adalah: Uji Normalitas

Uji hipotesis menggunakan beberapa uji yaitu uji mann-whitney.

\section{PEMBAHASAN}

Hasil percobaan pertama diperoleh data yang dilampilkan dalam bentuk diagram pada Gambarr 3-1. 


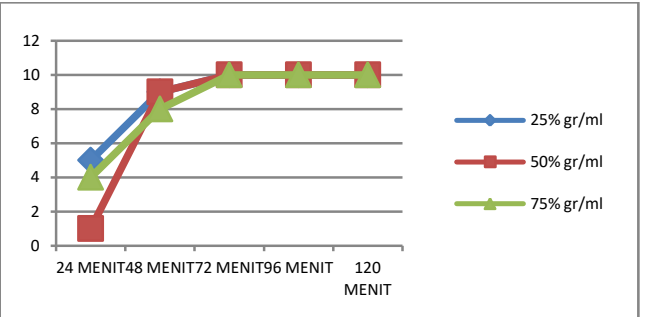

Gambarr 3-1 grafik data hasil percobaan pertama.

Data yang diperoleh dari percobaan pertama diketahui bahwa untuk konsentrasi $25 \%$ terjadi 5 ekor mengalami mortalitas sejak dari waktu pengamatan pertama (24 menit).

Selanjutnya pada waktu pengamatan kedua (48 menit) diperoleh fakta 4 ekor mati. sedangkan pada waktu pengamatan ketiga (72 menit) semua sampel telah mengalami kematian. Mortalitas sampel pada konsentrasi $50 \%$ terjadi 1 ekor mengalami kematian pada waktu pengamatan pertama. Selanjutnya, pada waktu pengamatn kedua (48 menit) diperoleh 8 ekor mengalami mortalitas, sedangkan pada waktu pengamatan ketiga (72 menit) semua sampel telah mengalami kematian. Mortalitas sampel pada konsentrasi $75 \%$ terjadi 4 mengalami kematian di waktu pertama, sedangkan pada waktu kedua (48 menit) ditemukan 4 mati, sedangkan pada waktu pengamatan ketiga (72 menit) semua sampel telah mengalami kematian.

Hasil percobaan kedua diperoleh data yang ditampilkan dalam bentuk diagram pada Gambar 3-2.

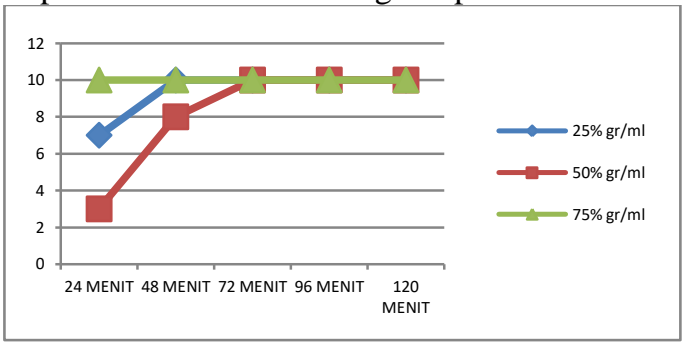

Gambar 3-2 grafik data hasil percobaan kedua.

Data yang diperoleh dari percobaan kedua diketahui bahwa untuk konsentrasi $25 \%$ terjadi 7 sampel mengalami mortalitas sejak dari waktu pengamatan pertama (24 menit) sedangkan pada waktu pengamatan kedua (48 menit) semua sampel mengalami mortalitas. Mortalitas sampel pada konsentrasi $50 \%$ terjadi 3 ekor mengalami kematian pada waktu pengamatan pertama. Selanjutnya, pada waktu pengamatn kedua (48 menit) diperoleh fakta 5 ekor mati, sedangkan pada waktu pengamatan ketiga (72 menit) semua sampel telah mengalami kematian. Selanjutnya mortalitas sampel pada kosentrasi $75 \%$ sampel mengalami mortalitas sejak dari waktu pengamatn pertama (24 menit).

Hasil penelitian pada percobaan ketiga diperoleh data yang ditampilkan dalam bentuk diagram pada Gambar 3-3.

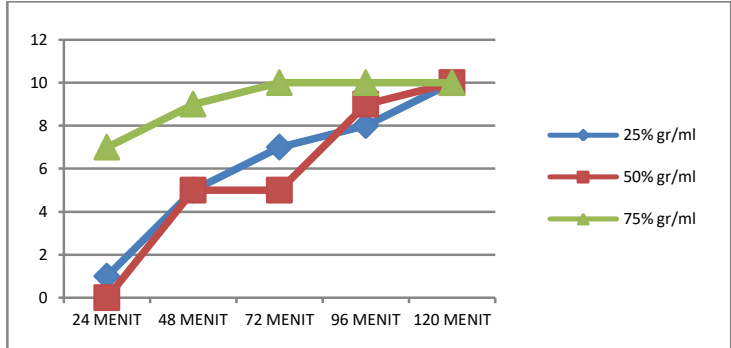

Gambar 3-3 grafik data hasil percobaan ketiga.

Data yang diperoleh dari percobaan ketiga diketahui bahwa untuk konsentrasi $25 \%$ terjadi 1 ekor mengalami kematian di waktu pengamatan pertama (24 menit), sedangkan pada watu pengamatan kedua (48 menit) terjadi 4 ekor mengalami kematian ,pada pengamatan ketiga yaitu (72 menit) 2 ekor mati, dan pada pengmatan keempat (96 menit) bertambah 1 ekor mati, sedangkan pada pengamatan terakhir (120 menit) semua sampel mengalami mortalitas. Mortalitas sampel pada kosentrasi $50 \%$ pada waktu pengamatan pertama (24 menit) belum ada yang mati,tetapi pada waktu pengamatan kedua (48 menit) terdapat 5 mati, pada pengamatan ketiga yaitu (72 menit) tidak ada yang mati, tetapi pada pengamatan keempat terdapat 4 mati, dan pada pengamatan terakhir (120 menit) semua sampel mengalami mortalitas. Mortalitas sampel pada kosentrasi 75\% terjadi 7 ekor sampel mengalami kematian di waktu pengamatan pertama (24 menit) sedangkan pada waktu pengamatan kedua (48 menit) ada 9 mati, dan pada pengamatan ketiga (72 menit) semua sampel mengalami mortalitas.

Hasil dari tiga perbandingan rata-rata penelitian data yang ditampilkan dalam bentuk diagram pada Gambar 3-4.

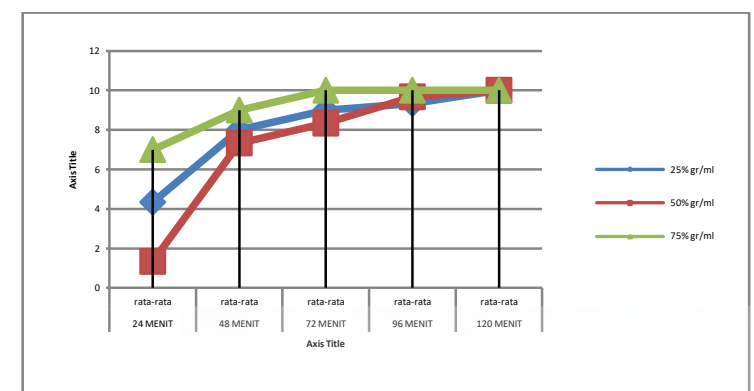

Gambar 3-4 grafik data hasil rata-rata.

Data yang di peroleh berdasarkan perhitungan rata-rata untuk masing-masing kosentrasi yakni pada konsentrasi $25 \%$ diperoleh nilai rata-rata terkecil yaitu 4.33 sedangkan nilai rata-rata terbesar yakni 10. Rata-rata untuk kosentrasi $50 \%$ di peroleh nilai rata-rata terkecil yaitu 1,33 sedangkan rata-rata terbesar yakni 10. Dan rata-rata untuk kosentrasi $75 \%$ di peroleh nilai rata-rata terkecil 7 sedangkan untuk rata-rata terbesar yakni 10 .

Hasil percobaan pertama pada kosentrasi 25\% Pomacea canaliculata Lamarck tampak tenang pada saat di berih larutan smilax $S p$ namun dalam 24 
menit 5 ekor Pomacea canaliculata Lamarck terapung, dan 6 lainnya terdiam di dasar air yang pada akhirnya semua media mengalami mortalitas. Pada kosentrasi $50 \%$ Pomacea canaliculata Lamarck mengalami kepanikan kemudian 1 ekor mulai naik lalu 1 ekor lagi terapung sementara 8 lainnya nampak diam di dalam air. Pada kosentrasi $75 \%$ Pomacea canaliculata Lamarck sangat panik terlihat 2 ekor naik ke atas permukaan wadah, lalu di menit ke24 ada 4 ekor terapung, dan 4 lainnya terdiam si dasar air. Dalam 3 kosentrasi pada 120 menit, semua Pomacea canaliculata Lamarck mengalami mortalitas dan tampak air yang di pakai menjadi berlendir.

Hasil percobaan kedua pada kosentrasi $25 \%$ terlihat dari menit ke 12 ada 1 Pomacea canaliculata Lamarck mulai panik dan naik ke atas permukaan wadah,lalu pada menit ke 16 terlihat 1 ekor lagi mulai panik dan lainnya melemah, selanjutnya pada menit ke 24 ada 7 ekor mati dan di menit selanjutnya yaiti 48 semua media mengalami mortalitas. Pada kosentrasi $50 \%$ dari mulai menit ke 9 sudah ada 1 keong yang panik dan naik ke permukaan wadah, selanjutnya di menit 29 ada 2 keong yang panic lalu naik ke wadah sedangkan 5 lainnya terdiam dan 3 mati, dan pada menit 48 bertambah menjadi 8 keong mengalami mortalitas sampai pada menit 72 semua keong mati. Pada kosentrasi $75 \%$ dati menit ke 7 sudah ada 1 keong yang panik lalu naik di atas permukaan wadah selanjutnya di menit ke 15 ada 2 keong yang panik dan naik, dan akhirnya mati semua di menit 24 .

Hasil percobaan ketiga pada kosentrasi pertama $25 \%$ di menit pertama tampak biasa, namun pada menit ke 24 ada 1 keong yang mati dan di menit 40 terlihat ada 3 ekor keong tampak panik 2 menempel di wadah, sementara 4 terdiam lalu 1 mati dan pada menit ke 96 dua ekor kong bertahan tetapi dengan keadaan lemas selanjut nya mati di menit 120 . pada kosentrasi $50 \%$ keong mulai panik pada menit ke 25 terlihat 1 keng naik kewadah, selanjutnya menit ke 42 keong naik 1 lalu 4 menempel di wadah, dan 5 terdiam yang selanjutnya keong yang terdiam mati pada menit 48,selanjutnya pada menit 62 ada 2 ekor naik dan 3 masih menempel. selanjutnya pada menit ke 96 ada 9 keong mati lalu 1 tampak lemas dan kemudian mati semua di menit 120. Pada kosentrasi $75 \%$ keong mulai panik pada menit ke 12 selanjutnya 1 ekor naik ke wadah pada menit ke 18, lalu pada menit ke 24 terdapat ada 7 keong mati yang lainnya lemas, pada menit ke 48 bertambah 2 keong mati dan akhirnya mati semua pada menit ke 72 . Dari semua percobaan hasil akhir yang di timbulkan dari larutan Smilax $S p$ air menjadi berlendir dan keong mati.

Uji Normalitas larutan $25 \%$ diperoleh nilai sebesar 0.000 , hasil perhitungan tersebut lebih kecil dari nilai alpha $=0,05$ maka dinyatakan data tersebut tidak normal.

Uji Normalitas larutan 50\% diperoleh nilai sebesar 0,000, hasil perhitungan tersebut lebih kecil dari nilai alpha=0,05 maka dinyatakan data tersebut tidak normal.

Uji Normalitas larutan $75 \%$ diperoleh nilai sebesar 0,001 , hasil perhitungan tersebut lebih kecil dari nilai alpha $=0,05$ maka dinyatakan data tersebut tidak normal. uji Normalitas larutan $25 \%$ diperoleh nilai sebesar 0,000 , hasil perhitungan tersebut lebih kecil dari nilai alpha $=0,05$ maka dinyatakan data tersebut tidak normal. Uji Normalitas larutan 50\% diperoleh nilai sebesar 0,000 , hasil perhitungan tersebut lebih kecil dari nilai alpha=0,05 maka dinyatakan data tersebut tidak normal. Uji Normalitas larutan $75 \%$ diperoleh nilai sebesar 100 , hasil perhitungan tersebut lebih besar dari nilai alpha $=0,05$ maka dinyatakan data tersebut normal. Uji Normalitas larutan 25\% diperoleh nilai sebesar 0,177, hasil perhitungan tersebut lebih besar dari nilai alpha $=0,05$ maka dinyatakan data tersebut normal. Uji Normalitas larutan 50\% diperoleh nilai sebesar 0,070, hasil perhitungan tersebut lebih besar dari nilai alpha $=0,05$ maka dinyatakan data tersebut normal. Uji Normalitas larutan 75\% diperoleh nilai sebesar 0,001, hasil perhitungan tersebut lebih kecil dari nilai alpha $=0,05$ maka dinyatakan data tersebut tidak normal.

Analisis hasil uji penelitian dalam penelitian ini yakni uji hipotesis. Uji hipotesis yang dilakukan berdasarkan hasil uji normalitas yang menyatakan data tidak normal maka menggunakan uji Mann-Whitney.

Uji hipotesis dilakukan dengan uji MannWhitney, karena hasil uji normalitas data yang ada perlakuan dan tanpa perlakuan dinyatakan tidak normal uji hipotesis tersebut untuk menjawab hipotesis berikut:

$\mathrm{H}_{0}=$ Perkembangan bakteri antara sampel yang diberi perlakuan dengan konsentrasi $25 \%$ dan lama waktu 12 jam dengan sampel tanpa perlakuan sama.

$\mathrm{H}_{1}=$ Perkembangan bakteri antara sampel yang diberi perlakuan dengan konsentrasi $25 \%$ dan lama waktu 12 jam dengan sampel tanpa perlakuan berbeda.

Syarat $\mathrm{H}_{1}$ diterima atau tidak berdasarkan nilai probabilitas sebagai berikut:

Apabila probabilitas $>0.05$ maka $\mathrm{H}_{0}$ diterima sedangkan $\mathrm{H}_{1}$ ditolak

Apabila probabilitas $<0.05$ maka $\mathrm{H}_{0}$ ditolak sedangkan $\mathrm{H}_{1}$ diterima

Berdasarkan hasil perhitungan di atas pada baris Asymp Sig terlihat bahwa nilai probabilitas .955. Maka keputusan yang diambil adalah $\mathrm{H}_{0}(.955>0.05)$ yang menunjukkan bahwa hipotesis $\mathrm{H}_{0}$ diterima sedangkan $\mathrm{H}_{1}$ ditolak. Jadi, $\mathrm{H}_{1}$ (jadi Larutan Smilax $S p$ tidak memiliki Aktivitas Moluskisida Terhadap Hama Pomacea Canaliculata Lamarck ) ditolak.

Uji hipotesis Ulangan Kedua Mortalitas dilakukan dengan uji Mann-Whitney, karena hasil uji normalitas data yang ada perlakuan dan tanpa perlakuan dinyatakan tidak normal uji hipotesis tersebut untuk menjawab hipotesis berikut: 
$\mathrm{H}_{0}=$ Perkembangan bakteri antara sampel yang diberi perlakuan dengan konsentrasi 25\% dan lama waktu 12 jam dengan sampel tanpa perlakuan sama.

$\mathrm{H}_{1}=$ Perkembangan bakteri antara sampel yang diberi perlakuan dengan konsentrasi 25\% dan lama waktu 12 jam dengan sampel tanpa perlakuan berbeda.

Syarat $\mathrm{H}_{1}$ diterima atau tidak berdasarkan nilai probabilitas sebagai berikut:

Apabila probabilitas $>0.05$ maka $\mathrm{H}_{0}$ diterima sedangkan $\mathrm{H}_{1}$ ditolak

Apabila probabilitas $<0.05$ maka $\mathrm{H}_{0}$ ditolak sedangkan $\mathrm{H}_{1}$ diterima

Berdasarkan hasil perhitungan di atas pada baris Asymp Sig terlihat bahwa nilai probabilitas .092. Maka keputusan yang diambil adalah $\mathrm{H}_{0}(.092>0.05)$ yang menunjukkan bahwa hipotesis $\mathrm{H}_{0}$ diterima sedangkan $\mathrm{H}_{1}$ ditolak. Jadi, $\mathrm{H}_{1}$ (jadi Larutan Smilax $\mathrm{Sp}$ tidak memiliki Aktivitas Moluskisida Terhadap Hama Pomacea Canaliculata Lamarck ) ditolak.

Uji hipotesis dilakukan dengan uji MannWhitney, karena hasil uji normalitas data yang ada perlakuan dan tanpa perlakuan dinyatakan tidak normal uji hipotesis tersebut untuk menjawab hipotesis berikut:

$\mathrm{H}_{0}=$ Perkembangan bakteri antara sampel yang diberi perlakuan dengan konsentrasi $25 \%$ dan lama waktu 12 jam dengan sampel tanpa perlakuan sama.

$\mathrm{H}_{1}=$ Perkembangan bakteri antara sampel yang diberi perlakuan dengan konsentrasi $25 \%$ dan lama waktu 12 jam dengan sampel tanpa perlakuan berbeda.

Syarat $\mathrm{H}_{1}$ diterima atau tidak berdasarkan nilai probabilitas sebagai berikut:

Apabila probabilitas $>0.05$ maka $\mathrm{H}_{0}$ diterima sedangkan $\mathrm{H}_{1}$ ditolak

Apabila probabilitas $<0.05$ maka $\mathrm{H}_{0}$ ditolak sedangkan $\mathrm{H}_{1}$ diterima

Berdasarkan hasil perhitungan di atas pada baris Asymp Sig terlihat bahwa nilai probabilitas .025. Maka keputusan yang diambil adalah $\mathrm{H}_{0}(.025>0.05)$ yang menunjukkan bahwa hipotesis $\mathrm{H}_{0}$ diterima sedangkan $\mathrm{H}_{1}$ ditolak. Jadi, $\mathrm{H}_{1}$ (jadi Larutan Smilax $S p$ tidak memiliki Aktivitas Moluskisida Terhadap Hama Pomacea Canaliculata Lamarck) ditolak.

Berdasarkan hasil hipotesis diperoleh fakta bahwa hipotesis yang diterima adalah daun smilax sp dapat mengakibatkan mortalitas terhadap keong. Hipotesis tersebut menunjukkan bahwa smilax sp memeilki kandungan sapoin yang memiliki aktifitas farmakologi yang cukup luas di antaranya meliputi immunamadulator, anti tumor, anti inflamasi, anti virus, anti jamur, dapat membunuh, kerang-kerangan, hiponglikemik, dan efek hipokolestrol (11). Dari hasil penelitian menjukan bahwa mortalitas paling cepat terjadi pada larutan $75 \%$ di karnakan banyak kandungan sapoin yang mengakibatkan keong tidak tenag dan selalu menghindar dari air yang terdapat larutan.

Adanya saponin dalam air menyebabkan terhambatnya proses pernafasan pada keong mas. Musman, (2011). Hal ini membuktikan bahwa semakin tinggi tingkat kepekatannya semaki tinggi bahan aktif yang dikandungnya, dengan demikian semakin tinggi pula daya bunuhnya (12). kronologi mortalitas keong mas yang terinfeksi larutan ditandai dengan perubahan tingkah laku keong mas yaitu Tubuh terus menerus mengeluarkan lendir dikarenakan terjadi kerusakan pada selaput lender, (13) mengemukakan bahwa keong mas bergerak mencari makan dengan cara membuka Operculum-nya dan menggerakkan kakinya. Keaktifan keong mas bergerak untuk mencari makanan mengakibatkan terjadi kontak tubuh dengan larutan Smilax $s p$ yang telah disemprot pada wadah, maka larutan Smilax $S p$ terakumulasi pada kaki sehingga keong mas mengeluarkan lendir. Namun dengan keluarnya lendir maka secara tidak langsung menghambat proses pernapasan dari keong mas dan mengakibatkan kematian. Berkurangnya cairan lendir pada tubuh keong mas mengakibatkan kekejangan otot pada kaki keong mas sehingga pergerakannya menjadi lambat. hal ini disebabkan senyawa yang masuk kedalam tubuh keong mas mengganggu kerja jaringan tubuh keong mas, proses ini mengakibatkan keong mas mati dengan cepat.

Hasil penelitian dapat dinyatakan bahwa tumbuhan Smilax $S p$ memiliki aktivitas sebagai moluskisida dengan kosentrasi mortalitas yang baik yaitu $75 \%$ dalam waktu 2. Mortalitas keong mas ditandai dengan keluarnya cairan lendir melalui celah Operculum atau kakunya pergerakan Operculum bila ditekan ke arah dalam. Fakta ini juga disokong oleh Musman, (2004) yang meneliti aktivitas mongulisida dengan menggunakan Uji selektivitas ekstrak etil asetat (EtOAc) biji putat air (Barringtonia racemosa) terhadap keong mas (Pomacea canaliculata) dan ikan lele lokal (Clarias batrachus). Hasil penelitian menunjukkan bahwa persentase mortalitas meningkat seiring dengan peningkatan konsentrasi ektrak biji putat.

\section{KESIMPULAN}

Hasil penelitian dapat di simpulkan bahwa larutan Smilax Sp memiliki aktivitas moluskisida terhadap hama Pomacea Canaliculata Lamarck dengan kosentrasi larutan yang optimal $75 \%$ selama 2 jam.

\section{DAFTAR PUSTAKA}

1. Komposisi dan Kelimpahan Moluska (Gastropoda dan Bivalvia) di Ekosistem Mangrove Muara Sungai Musi Kabupaten Banyuasin Provinsi Sumatera Selatan. Hartoni \& Agussalim. 2013, Maspari Journal, 5(1), pp. 6-15. 
2. Predatory potential of freshwater animals on an invasive agricultural pest, the apple Snail Pomacea Canaliculata (Gastropoda: Ampullariidae), in Southern Japan.. Yusa et al. 2006, Biological Invasions 8, pp. 137-147.

3. L, Jianbin. Study Of Plant Molluscicide From Jatropha curcas seed (JCS) In Laboratory. s.l. : Hubei Institute Of Schistosomiasis Control., 2000.

4. Pengembangan Kinerja Anti moluska dari Tanaman Jayanti \{ sesbania sesban (L.) Merr. Suripto et al. 2008, untuk Mengendalikan Keong Mas Hama Tanaman Padi.

5. Predatory potential of freshwater animals on an invastive agricultural pest, the apple snail pomacea canaliculata (Gastropoda: ampullariidae), in southrn japan. Yusa et al. 2006, Biological inovasions 8, pp. 137-147.

6. Pengaruh Buah Pinang (Areca Catechu) Terhadap Mortalitas Keong Mas (Pomacea Canaliculata) Pada Berbagai Stadia. Gassa, A. 2011, J. Fitomedika, pp. 171-174.
7. Steroidal Saponins from the Rhizomes . Zhang et al. 2012, And Roots of Smilax scobinicaulis. Phytochemistry Letters, pp. 49-52.

8. . Steroidal Saponins from the Roots of Smilax sp. Challinor et al. 2012, Structure and Bioactivity. Steroids 77, pp. 504-511.

9. Antioxidant Activity of Smilax excelsa L. Leaf Extracts. . Ozsoy et al. 2008, Food Chemistry 110, pp. 571-583.

10. Psikologi Eksperimen. Latipun. 2004, pp. 70-71.

11. Tumbuhan obat dan khasiatnya seri 3 . Hariana.A.H. 2013, jakarta: penebarswadayah.

12. pengaruh pemberian ekstrak bawang putih terhadap mortalitas keong mas. Rusdy, A. 2010, jurnalj.floratek 5 unsia banda aceh, pp. 127-180.

13. Uji selektivitas ekstrak etil asetat (EtOAc) biji putat air (Barringtonia racemosa) terhadap keong mas (Pomacea canaliculata) dan ikan lele lokal (Clarias batrachus). Musman, M. 2011, pp. 20897790 . 